\author{
Anastasiya VINAKURAVA ${ }^{1}$ \\ Andrzej SKRZAT ${ }^{2}$
}

\title{
BIOMECHANICAL PROPERTIES OF HIP IMPLANT WITH CERAMICS COATING
}

\begin{abstract}
In this paper the results of investigations of biomechanical properties of transplantation of hip bone with ceramic coating are presented. The finite element analysis of the stress-strain state of the femur bone after hip replacement surgery and full recovery period are carried out. A finite element model of the femur bone is obtained on the basis of tomographic data of 36 years old male patient. A transplant stem with ceramic coating based on A400 lateralized specification was analyzed. Stresses in the intact femur and femur after arthroplasty were determined. The effect of the reduction of bone density as the result of removal of normal stresses by an implant were analyzed. The study serves as a biomechanical basis for development of artificial prostheses and for clinical hip joint replacements.
\end{abstract}

Keywords: arthroplasty, finite element method, strain-stress state, intact femur, hip transplant, stress shielding

\section{Introduction}

The hip joint is one of the biggest and highly stressed joints. It bears our body's weight, allows us to walk, run and jump. Osteoarthritis, rheumatoid arthritis, osteonecrosis, injury, fracture, and bone tumors can damage this joint. Osteoarthritis is the most common form of joint disease and it is also known as degenerative arthritis. It occurs in a process of cartilage wearing down with age. Patients with hip joint damage that causes pain and interferes their daily activities despite treatment can be candidates for hip replacement surgery. Joint Replacement is often the only way to restore joint function to improve the quality of patient's life. In a process of surgery damaged parts of joint are replaced with an artificial joint. Artificial joints are made from materials that must have compatibility with biological tissues, non-toxic. They also have to be bioactive and carry the physiological load.

\footnotetext{
${ }^{1}$ Autor do korespondencji/corresponding author: Anastasiya Vinakurava, Rzeszow University of Technology, 8 Powstańców Warszawy Av., 35-959 Rzeszów, tel.: +48 178651555, e-mail: vinakurava@ prz.edu.pl

${ }^{2}$ Andrzej Skrzat, Rzeszow University of Technology, e-mail: askrzat@prz.edu.pl
} 
Hydroxyapatite calcium phosphate ceramic is found to be the major component of the bone what makes it one of the most effective biocompatible materials for hip implant coating. According to clinical studies, a hip replacement must ensure stable functioning for 20 years. However, after hip replacement surgery may occur some complications. One of them is the stress shielding that can reduce for twice time of use of the implant. This term refers to the reduction in bone density (osteopenia) as a result of removal of normal stress from the bone by an implant (for instance, the femoral component of a hip prosthesis) [1]. A lot of finite element studies were carried out to assess the influence of the hip implant. Recently obtained results and the history of the development of this problem are described in [2-4]. Usually, in the works related to the calculation of the stress-strain state of hip implant system effect of stress shielding is not considered. The hip transplant with hydroxyapatite coated stem was investigated in clinical studies [2,11]. The specification of a material model for a bone and transplantation in finite element studies is still relevant. The aim of this study is to investigate the biomechanical properties of replacement of the hip bone with ceramic coating and to compare it with an intact femur bone.

\section{Materials and methods}

Stereolithography (STL) model of the cortical bone and sponge body were obtained with the use of MIMICS 14.12 (Materialise BV) on the basis of 55 tomographic images of the dry cadaveric femur of adult men. The step of tomographic slices is $1 \mathrm{~mm}$. A similar approach was used in [3, 4] and [14], during development of the three-dimensional solid model of the femur bone. For modeling the hip replacement femoral head and neck were removed from the model. The simulation of bone marrow was not carried out, because it has little influence on the stress distribution in the bone structures of the femur bone under static load.

A solid model of hip transplant was created using 3D CAD tools of SolidWorks 2010 (SolidWorks Corporation, USA) on the basis of A400 lateralized specification. Stem was installed to the femoral shift opening. The stem length is equal to $133.6 \mathrm{~mm}$ and the distance of neck axis is 53.5. The width of proximal cross section and distal cross section is $30.4 \mathrm{~mm}$ and $7 \mathrm{~mm}$ respectively. These properties correspond to the size 6 of the A400 specification. Finite element models of the intact femur, femur after total hip replacement and hip implant were derived by using ANSYS Workbench. The maximum size of the element is $3 \mathrm{~mm}$. The properties of finite element model can be seen in a table 1 . The type of the finite element is Solid72. Contacts between the hip implant and femur, as well as compact and sponge bones were assigned via contact elements Conta173, Conta174 and Targe170 (without sliding and penetration) what can be interpreted as fully recovering after surgery. The boundary conditions for the femur correspond to rigid fixing of half $[2,3,6]$. The finite element model of the 
femur bone after hip replacement surgery and locations of muscle attachment area are shown in figure 1.

Table 1. Finite element model description

\begin{tabular}{|l|l|l|}
\hline Part & Number of elements & Number of nodes \\
\hline Intact femur & 77019 & 123148 \\
\hline Post-surgery femur & 50288 & 82420 \\
\hline Hip transplant & 8022 & 12900 \\
\hline
\end{tabular}

(a)

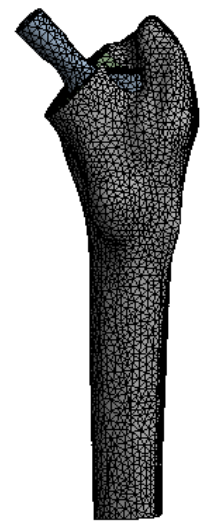

(b)

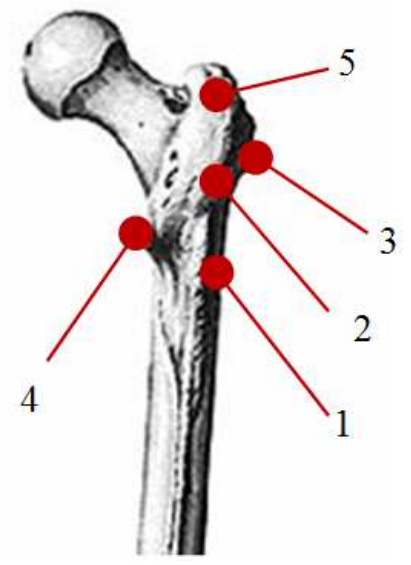

Fig. 1. Finite element model of femur bone after hip replacement surgery $(a)$ and location of muscle attachment area (Table 2) (b)

According to some authors [5] muscle loads had a significant influence on stress distribution. Magnitude of nodal forces shown in Table 2 corresponds to midstance phase of walking [4] directly associated with the period of single-leg support of body weight or the period during which the body advances over the stationary foot. Boundary conditions correspond to rigid fixing of the nodes created after the transversal cut. The force applied to the femur and the stem head is $800 \mathrm{~N}$ (corresponding to average weight). The elastic properties of the bone tissues and hip implant are presented in Table 3. They corresponds to data in [7]. The cortical bone and the trabecular bone were taken as orthotropic homogenous. The properties of hydroxyapatite are taken from the research $[2,8]$. Stress-strain states of the femur bone after the total hip replacement were derived for two cases. In the first case only titanium stem without any coating was used. In the second case bioceramic coating was considered. For comparison with the results stress-strain analysis of intact bone was carried out. 
Table 2. Magnitude of muscular forces

\begin{tabular}{|c|c|c|c|}
\hline \multirow{2}{*}{ Load } & \multicolumn{3}{|c|}{ Magnitude } \\
\cline { 2 - 4 } & $\mathrm{X}$ & $\mathrm{Y}$ & $\mathrm{Z}$ \\
\hline Gluteus maximus (1) & -105 & 172.3 & 203.8 \\
\hline Musculus gluteus medius (2) & 28.9 & 63.7 & 113.3 \\
\hline Musculus gluteus minimus (3) & -0.7 & 25.4 & 51.6 \\
\hline Musculus psoas major (4) & 160.6 & 3.6 & 158.6 \\
\hline Musculus piriformis (5) & -70.1 & 110.5 & 22.4 \\
\hline
\end{tabular}

Table 3. Elastic properties of materials

\begin{tabular}{|c|c|c|c|}
\hline Materials & $\begin{array}{c}\text { Elasticity modulus } \\
\mathrm{GPa}\end{array}$ & Poisson's ratio & $\begin{array}{c}\text { Shear modulus } \\
\mathrm{MPa}\end{array}$ \\
\hline Titanium & 110 & 0.31 & - \\
\hline $\begin{array}{c}\text { Ceramics (hy- } \\
\text { droxyapatite) }\end{array}$ & 3.9 & 0.21 & - \\
\hline & $\mathrm{E} 1=4.3$ & $\mathrm{v} 12=0.40$ & $\mathrm{G} 12=5.71$ \\
Compact bone & $\mathrm{E} 2=4.3$ & $\mathrm{v} 23=0.25$ & $\mathrm{G} 23=7.11$ \\
& $\mathrm{E} 3=7.8$ & $\mathrm{v} 31=0.25$ & $\mathrm{G} 31=6.58$ \\
\hline & $\mathrm{E} 1=1.2$ & $\mathrm{v} 12=0.40$ & $\mathrm{G} 12=5.71$ \\
Sponge bone & $\mathrm{E} 2=1.2$ & $\mathrm{v} 23=0.25$ & $\mathrm{G} 23=7.11$ \\
& $\mathrm{E} 3=2.1$ & $\mathrm{v} 31=0.25$ & $\mathrm{G} 31=6.58$ \\
\hline
\end{tabular}

\section{Results and discussion}

Results of equivalent stresses in the femur bone under static pressure can be seen in figure 2. In the case of intact femur (a) higher stresses appear under lesser trochanter (maximum value in this area $107.84 \mathrm{MPa}$ ) and propogate to pectenial line. Stresses higher than $80 \mathrm{MPa}$ also appear in the area of neck and greater trochanter. Distribution of stresses in the case the hip bone with ceramic coated implant (b) significantly differs because higher stresses arise mostly inside the bone structure (maximum value is $139.68 \mathrm{MPa}$ ) and appear in the area of pectineal line and gluteal tuberosity. However, it is also worth to mention that long bones have very high ultimate tensile strenght that is equal to 130-170 MPa. It is important to notice, that in all three cases high stresses appear in the transversal plane because of concentration of stresses. To avoid such problem in future and to get more accurate results it is better to use the whole model of the femur, even if it will increase the time of calculation and the size of the model. One of the important indicator that allows to predict complications like bone resorption is the shear stresses [3]. The results of biomechanical systems for implants with and without ceramic coating are presented in figure 3. Also noted that in the case (a) maximum shear stress is equal to $113.95 \mathrm{MPa}$ and in the case of (b) shear stress is equal to $128.89 \mathrm{MPa}$. In both cases highest stresses appear in the area of stem. Such results confirm that it is very important to consider increasing a contact area of the implant with a bone structure by using coating in a stem area or even choosing implant with a bigger stem. 
(a)

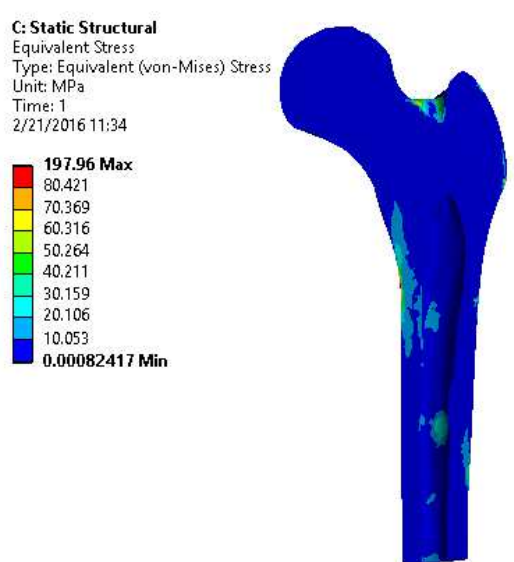

(b)

D: Static Structural

Type: Equivalent (von-Mises) Stress

Unit: $\mathrm{MPa}$

Time: 1

2/21/2016 11:19

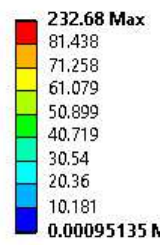

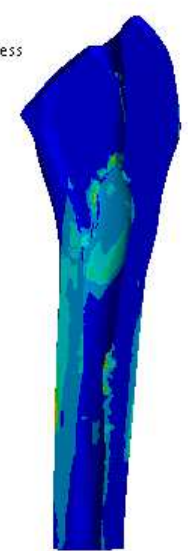

Fig. 2. Equivalent stresses for intact femur $(a)$ and the femur after hip-replacement $(b)$

(a)

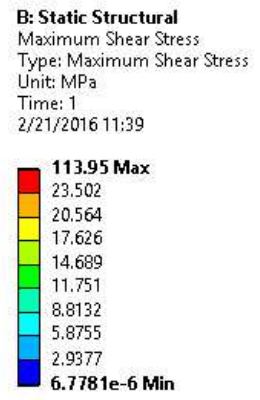

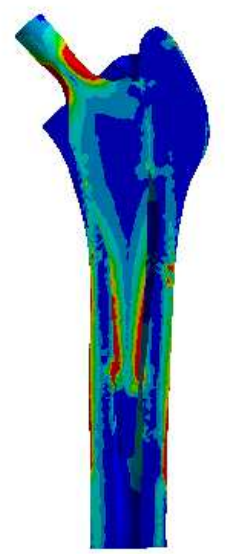

(b)

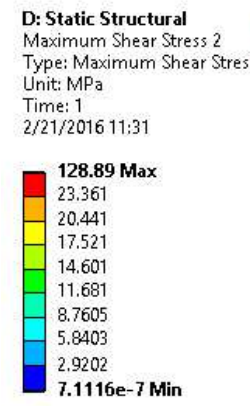

D: Static Structural

Type: Maximum Shear Stress

Unit: MPa

2/21/201611:31

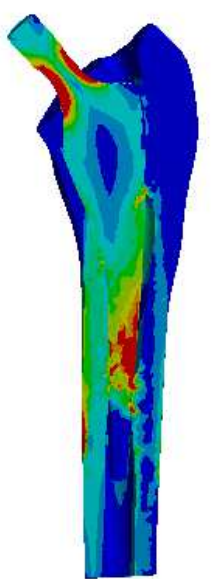

Fig. 3. Shear stresses for femur after hip-replacement with titanium implant (a) and ceramic coated $(b)$ transplants

The comparative analyses of stresses for selected area of the femur bone are presented in figure 4 . The areas with the high stresses in thecase of intact femur were selected: between lesser trochanter and pectenial line (probe 1), greater troachanter (probe 2) and gluteal tuberosity (probe 3). The difference between biomechanical systems with implant with or without bioceramic coating is not essential, however in comparison with intact femur magnitude of stresses in the tested area drop drastically. Such significant changes can cause processes of 
adaptation like stress shielding in the future that can lead to loss of bone density and to further damage.

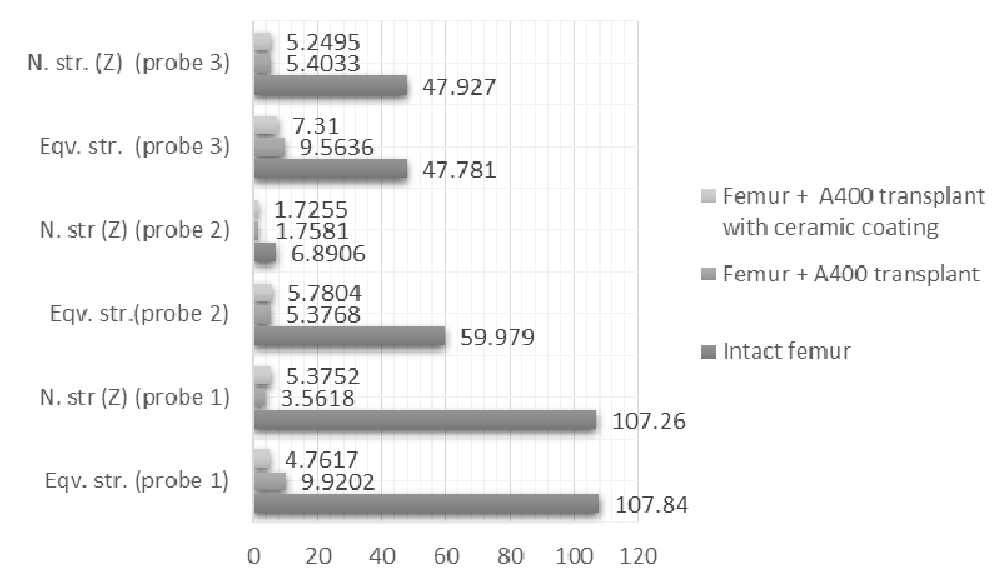

Fig. 4. Maximum equivalent and normal stresses for selected area of femur for different model configurations

\section{Conclusions}

The finite element analysis of the femur bone after hip replacement surgery was carried out. Such approach allows to explain the clinically observed effects $[1-5,11,12]$. The computations of the femur after hip-replacement surgery showed that the presence of the implant significantly affects the distribution of stresses in the structure in comparison with the intact bone that can lead to stress shielding and bone resorption and can reduce the time of using implant in the future. It is worth noting that the firm connection between implant with ceramic coating and the bone leads to more steady load distribution and can provide more successful adaptation of bone tissues and helps to avoid such complications. However, too high values of maximum shear stresses in both cases for femur after joint replacement indicate the need to further studies of the influence of the size of the stem on the stress-strain state of the biomechanical system.

In the further investigation more sophisticated approach for the contact between the bone and transplant is needed. The use of the application corresponded to the micropolar theory for more realistic behavior of bone tissues and ceramic material also considered.

\section{Acknowledgment}

The research leading to these results has received funding from the People Program (Marie Curie Curie ITN transfer) of the European Union's Seventh Framework Programme 
for research, technological development and demonstration under grant agreement No PITN-GA-2013-606878.

\section{References}

[1] Ridzwan M.I.Z., Shuib S., Hassan A.Y., Shokri A.A., Mohamad Ibrahim M.N.: Problem of stress shielding and improvement to the hip implant designs: A Review - J. Medical Sci., 7 (2007) 460-467.

[2] Herrera A., Mateo J, Gil-Albarova J., Lobo-Escolar A., Ibarz E., Gabarre S., Más Y., Gracia L.: Cementless Hydroxyapatite Coated Hip Prostheses, BioMed Research Int., 2015 (2015) Article ID 386461, 13 pages.

[3] Nikitsin A.V., Mikhasev G.I., Maslov A.P: Finite element analysis of the porous coating in hip-joint prosthesis, Int. Sci. Tech. J. "Mechanics of Machines, Mechanisms and Materials", 18 (2012) 86-89.

[4] Mohammed R.A.: Interface micromotion of cementless hip stems in simulated hip arthroplasty, American J. Appl. Sci., 6 (2009) 1682-1689.

[5] Tonino A.J., Therin M., Doyle: Hydroxyapatite-coated femoral stems. Histology and histomorphometry around five components retrieved at post mortem, J. Bone Joint Surgery, 81 (1999) 148-154.

[6] Alexander R.: Animals mechanics, Singwick \& Jackson, London 1968.

[7] Fonseca E.M.M., Lima M.J., Barreirra L.M.S.: Human femur assessment using isotropic and orthotropic materials dependent of bone density, 3rd Int, Conf, on Integrity, Reliability and Failure, Porto 2009, pp.7-8.

[8] Orlovskii V. P., Komlev V. S., Barinov S. M.: Hydroxyapatite and hydroxyapatite-based ceramics, Inorganic Materials, 38 (2002) 973-984.

[9] Huiskes R., Rietbergen B.: Preclinical testing of total hip stems. The effects of coating placement, Clinical Orthopaedics Related Res., 319 (1995) 64-76.

[10] Rosenthall L., Bobyn J.D., Tanzer M.: Bone densitometry: influence of prosthetic design and hydroxyapatitecoating on regional adaptive bone remodelling, Int. Orthopaedics, 23 (1999) 325-329.

[11] Nakashima Y., Sato T., Yamamoto T. : Results at aminimum of 10 years of follow-up for AMS and PerFix HA-coated cementless total hip arthroplasty: impact of cross-linkedpolyethylene on implant longevity, J. Orthopaedic Sci., 18 (2013) 962-968.

[12] Park Y.S., Lee J.Y., Yun S.H., Jung M.W., Oh I.: Comparison of hydroxyapatiteand porous-coated stems in total hip replacement, Acta Orthopaedica Scandinavica, 74 (2003) 259-263.

[13] Tas A.C., Ozgur E.: Manufacture of macroporous calcium hydroxyapatite bioceramics, J. Eur. Ceram. Soc., 19 (1999) 2569-2772.

[14] Yosibash Z:: A CT-based high-order finite element analysis of the human proximal femur compared to in vitro experiments, J. Biomech., 129 (2007), 297-309.

[15] Bergmann G: Hip contact forces and gait patterns from routine activities, J. Biomech., 34 (2001) 859-871. 
[16] Bojescul J.A.: Results of porous-coated anatomic total hip arthroplasty without cement at fifteen years: a concise follow-up of a previous report, The J. Bone and Joint Surgery, 85 (2003) 1079-1083.

[17] Duchemin L.: Prediction of mechanical properties of cortical bone by quantitative computed tomography, Medical Eng. Physics, 30 (2008) 21-328.

[18] Simões J.A., Vaz M.A., Blatcher S., Taylor M.: Influence of head constrain and muscle forces on the strain distribution within the intact femur, Medical Eng. Physics, 22 (2000) 453-459.

\section{WŁAŚCIWOŚCI BIOMECHANICZNE PRZESZCZEPU KOŚCI BIODROWEJ Z POWLOKĄ CERAMICZNĄ}

\section{Streszczenie}

W artykule przedstawiono wyniki badań właściwości biomechanicznych przeszczepu kości biodrowej z powłoką ceramiczną. Przeprowadzono analizę metodą elementów skończonych stanu naprężeń i odkształceń kości udowej po zabiegu wymiany stawu biodrowego i po pełnym okresie rekonwalescencji. Model kości udowej wykorzystany do analizy metodą elementów skończonych otrzymano na podstawie danych termograficznych 36-letniego pacjenta. Analizie poddano rdzeń przeszczepu okryty powłoką ceramiczną na podstawie specyfikacji A400. Wyznaczono naprężenia w kości udowej nienaruszonej i po endoprotezoplastyce. Analizowano wpływ zmniejszenia gęstości kości jako wyniku usunięcia naprężeń normalnych przez implant. Badania stanowią podstawę biomechaniczną do opracowywania sztucznych protez stawu biodrowego i klinicznych wymian połączenia biodrowego.

Słowa kluczowe: endoprotezoplastyka, metoda elementów skończonych, stan naprężeń i odkształceń, kość udowa, przeszczep biodra, osteopenia

DOI: $10.7862 / \mathrm{rm} .2016 .6$

Otrzymano/received: $24.02 .2016 r$.

Zaakceptowano/accepted: 15.03.2016 $r$. 